[Clark, J. (2004). Education Myths as a Framework for Education Policy: Towards a New Myth. New Zealand Annual Review of Education, 13, 5-19]

\section{Education Myths as a Framework for Education Policy: Towards a New Myth}

\section{JOHN CLARK}

\section{Abstract:}

The idea of an "Education Myth" was offered by C. E. Beeby as an over-arching policy framework which would permit a coherent set of policies to be developed in a systematic way. This paper outlines exactly what an education myth is, and then considers three such myths in New Zealand's education history: 1877 and survival of the fittest; 1939 and equality of educational opportunity; and 1987 and education as a commodity. A fourth myth is proposed for 2003 onwards - educated citizens in a democratic society.

t the national level, policies are made on a wide variety of
educational matters, including assessment, curriculum, funding,
qualifications and the like. More specifically, particular education
policies such as special education mainstreaming or tertiary student
loans are introduced to address pressing problems or effect new
directions. These are sometimes planned for well in advance, while on
other occasions their introduction is extremely rushed. What is
obvious is that all of these policies cannot be put into effect at the
same time. They are strung out over a lengthy period, marked by
changes of government and altered circumstances. Given this, if ad
hoc, uncoordinated and contradictory policies are to be avoided, then
there needs to be some sort of over-arching framework which permits
a coherent set of policies to be developed in a systematic way. The
device for achieving this, suggests Beeby (1986), is the education myth.
Exploring this idea, Beeby observed the prior existence of two
myths in New Zealand education dating back to 1877 and 1939

\section{John Clark}

respectively, and in 1986 he predicted the emergence of a third. He was both right and wrong with his prediction: right insofar as a third did emerge the following year; wrong as to its character. But this myth, too, has run its course and is in need of replacement by a new vision of what schooling and education ought to be about.

Accordingly, this article begins with an account of education myths, examines the three myths in New Zealand's education history sets out principles for developing a new education myth and concludes with a statement of a new educational vision.

\section{Educational Myths}

For Beeby, a myth is not something to be disparaged, since some of the noblest human achievements are myths and are devised to give a measure of stability in a changing world. Myths are "unattainable but approachable goals", and a myth must meet certain requirements:

It must in general accord with some strong - though not always clearly defined - public aspirations; it must be expressed in a language flexible enough to permit a reasonably wide range of interpretations, and yet specific enough to provide practical guidance to administrators, planners and teachers; it must be unattainable, at least for that generation, if it is to sustain twenty five years of change without being constantly and confusingly modified. With the wisdom of hindsight, we now know that it is unattainable in another more subtle sense, that, by the time it is close enough to be seen clearly, its weaknesses will have become apparent, and a rival myth will be edging its way into the centre of vision. (pp. $x v-x v i)$

The first educational myth: 1877 and Survival of the Fittest The Educational Act of 1877 introduced a national system of schooling providing for up to eight years of primary education for all and secondary schooling for some. Although strong parliamentary support was given to compulsory primary schooling, this universal provision was rejected for secondary schooling, according to Bowen (1877), one of the prime movers of the bill, because members opposed it on the grounds that education should not be wasted on the undeserving; there was no intention

to encourage children whose vocation is that of honest labour to waste in the higher schools time which might be better devoted to 
learning a trade, when they have not got the special talent by which that higher education might be made useful. (p. 39)

This Darwinian "survival of the fittest", "that, if the state gave a minimum of free elementary education to every child, those with the greatest natural ability would somehow fight their way towards the top" (Beeby, 1986, pp. xvii-xviii) took on the mantra of an education myth, having practical application in the proficiency examination. It lasted in the public consciousness until at least the early 1930s, when the Wellington Chamber of Commerce (1933) stated

Speaking generally, the children of unenlightened parents would not gain benefit from a longer period at school and it was a matter for serious consideration whether, after passing the fourth standard, children of but moderate mental development should not be definitely prepared for the type of work for which their mental capacity and natural ability make them best suited. It might be that further education along general lines would not fit them for the modest role nature intended them to play in life....It is a matter for consideration whether the view should not be placed before boys that the unskilled labourer is not entitled under natural law or under the principles of justice to the luxuries of life, but to little more than the basic necessities.

Two years later, in 1935, the first Labour government was elected; the following year the proficiency examination was abolished and a free secondary education became available to all, and three years on again, a new educational myth emerged.

\section{The second educational myth: 1939 and Equality of Educational}

Opportunity

The world depression of the early 1930s, the appointment of Peter Fraser as Minister of Education, and the 1937 New Education Fellowship Conference led to a public demand for change to the education system. This was soon to come, in the now widely quoted Beeby/Fraser statement of 1939:

The Government's objective, broadly expressed, is that every person, whatever his level of academic ability, whether he is rich or poor, whether he live in town or country, has a right, as a citizen, to a free education of the kind for which he is best fitted, and to the fullest extent of his powers. So far is this from being a mere pious platitude that the full acceptance of the principle will involve the reorientation of the education system. (Beeby, 1992, p. 124)
Grace (1991) claims that this statement set out a conception of education as a public good and contained five principles which were to structure educational policy from 1939 onwards. Four of these principles were of provision, the fifth of enactment:

(1) a principle of equal educational opportunity ("that every person whatever his [sic] level of academic ability"); (2) a principle of education as a right of citizens ("has a right as a citizen"); (3) a principle of free education ("a free education of the kind for which he is best fitted); and (4) a principle of generous and extensive provision ("to the fullest extent of his powers"). While the fifth principle was less explicitly stated there can be no doubt that the concluding references to "will involve the reorientation of the education system" implied, given the stance of the 1st Labour Government, that central government education agencies would be the mechanism for "reorientation". In other words, the principle of enactment in this educational settlement was a principle of state agency. The state would be the mechanism for the realisation of equity in education. (pp. 265-266)

For the next fifty years, this educational philosophy was to guide and govern the role of the state in the provision of education in New Zealand. Beeby (1986) later observed that "the principle did lay down a general direction of desirable change and was a fairly reliable touchstone to test whether any programme for action fell within its limits", such that "any proposal to raise the cost to parents...or reduce the choice of courses...would have offended against it" (p. xxiii).

But in 1986 Beeby acknowledged the many objections to the prevailing education myth and in his introduction to Renwick's (1986) Moving Targets, Beeby predicted the emergence of a third education myth based on Renwick's notion of "equality of results". However, by 1992, Beeby had recognised the criticism raised by the "radical left" against both Fraser's myth of equality of opportunity and Renwick's idea of equality of results; equally, he found that the radical left had been eclipsed by the radical right. He would comment on neither, except to remark that "whichever policy wins, if it lasts long enough it is destined to become a myth" (Beeby, 1992, p. 304). In his concluding paragraph he remarked, "it is interesting to conjecture what the myth will be by the turn of the century. I shall never know" (p. 304). He died in 1998. But, as we now know, it was the radical right that prevailed. 


\section{The third educational myth: 1987 and Education as a Commodity}

The 1939 educational settlement lasted for fifty years until it was called into question and replaced by a new myth. In their Brief to the Incoming Government, the New Zealand Treasury (1987) presented a complete volume on government management devoted to education. Treasury pointed out that government intervention falls into three categories: "The Government provides education and training services and information about these services, it subsidises the consumers of its services and the services of other providers and it regulates the production of these services" (p. 1). Treasury concluded that the national system of education was coming under increasing strain in an environment of rapid change:

The demands on the education system to fit and refit people for work are increasing enormously. Ironically, at the same time, rising unemployment, often linked to technological change, leads many to see the system as also having to prepare people for non-work, that is for unemployment and leisure. Thus a key current question to be addressed in this brief is whether the mechanisms for change in education policy, which worked well in more leisurely times, are up to the sudden gear shifts that are increasingly required if the system is to adapt to the fast changing and increasingly varied needs of society. (p. 4)

Treasuryidentified four functions of education: fulfilment, integration, custodial and economic:

Society may benefit from having citizens who feel fulfilled and whose abilities are developed (the fulfilment function) and who are well socialised both within their immediate community and the wider society, who in a democracy can make informed decisions and who are adaptable to different or changing social situations (the integrative function). These benefits will largely be reaped in the future rather than directly at the time the education is given and are thus an investment by society in the future. Society can benefit from having children at risk kept safely in custody during school hours and from the free time for economic or leisure use that the child's parents will gain (the custodial function). These benefits will largely occur at the time education is given.

Society can benefit from individuals who possess the discipline, skills and talents needed by the economy and which can, as necessary, be developed further, and from the certification of the level of knowledge, skill and likely degree of trainability for work needs possessed by individuals (the economic function). (pp. 29-30)

From this, Treasury arrived at a new educational myth:

Education's investment benefits, which bring long-term benefits to society as well as the individual, may lie behind the feeling that education does not belong in the marketplace. Education tends to be thought of as a natural sphere for government intervention because it is a social or public good and because of concerns about equity in the private costs and benefits flowing from education. In the technical sense used by economists, education is not in fact a "public good". Pure public goods possess the characteristics of being non-exclusive, that is, individuals cannot be excluded from enjoying them (for example defence), non-competitive, that is, the marginal cost of another individual enjoying the good is zero (for example an empty railway compartment) and non-positional, that is, the value does not lie in restricted supply (for example prestige goods). The provision of formal education and the associated educational qualifications does not fall into these categories. Individuals can be excluded from provision and persons outside compulsory school age are excluded (even with compulsory school age, zoning, and private schools depend on being able to exclude individuals). The marginal cost of provision is not zero and the value of educational qualifications does, at least in part, lie in their scarcity. Hence, education shares the main characteristics of other commodities traded in the market place. (pp. 32-33)

Although not as elegantly expressed as the Fraser myth, Treasury's myth encapsulates a profoundly different educational ideal. Whereas the former set out a social contract between the individual and the state such that individuals had equal entitlement to a free education provided by the state, the new myth promoted a contractual arrangement of a very different kind, of individuals paying in an unequal private market:

Where the individual or their agent contracts directly with the provider of education, the balance of perceived costs and benefits of education to individuals and their agents will determine the demand for education. An individual or their agent will normally pursue education for that individual to the point where the costs to the individual/agent of an additional element of education outweigh the benefits. In such market conditions, the nature and extent of this demand for education will call forth the appropriate 
supply. To the extent that the costs and benefits accrue to some individual, that person may be best left to determine the course of action for themselves, that is, choose the nature and extent of education he or she is to undertake. Between the customer and the provider an implicit or explicit contract exists. This bundles together for each party: who chooses, who pays..., who benefits... and who is accountable for delivery of the service concerned. (p. 31)

Apple (1991) has identified two effects of this ideological shift to the right:

1. It makes schools more like the free market economy. This economy reduces the role of the state in making decisions about what is good for its citizens, and increases the role of individuals in making free, informed and responsible choices according to their own best interests.

2. There is growing pressure to make the needs of business and industry into the primary goals of the school system. (p. 8)

These two ideas come together in the pronouncement of Alistair Rivers, a community liaison manager responsible for building relationships between the business community which he served and a Christchurch secondary school:

I see the school as being nothing more than a very finely focused factory and like any factory, we import product. In our case, it's students, and we then, like any factory, add value to that product, in our case the children, and we eventually aim to produce a product that is both in demand and appropriately skilled to meet the expectations of the marketplace. And the marketplace is the community, the business, the husbands or wives or partners that they will become. (Rivers, 1996, p. 10)

There are two logical implications of this view:

1. In respect to values, although the market is held to be more efficient and cost-effective because it allows consumers to make their own individual (and hopefully informed) choices from a range of competing schools, the market itself has no moral concerns beyond meeting the needs of consumers. What is good, right or proper is left for individuals to discern in accordance with their own self-interests. There is no room for a wider social morality.
2. If schools are to be organised and administered like factories, and if children and their learning are held to be no more than new products for factories to process, then children are being treated as no more than the means to other people's ends. But there is something morally objectionable about treating children in this rather undignified way. Children, like adults, are moral agents and as such deserve, and have the right, to be treated as ends in themselves.

We have lived with this education myth for over fifteen years. It is now perhaps timely that we should be reminded again of Beeby's (1986) insight about educational myths: "with the wisdom of hindsight, we now know that it is unattainable in another more subtle sense, that, by the time it is close enough to be seen clearly, its weaknesses will have become apparent, and a rival myth will be edging its way into the centre of vision" (p. xvi). There has been enough criticism (e.g., Clark, 1998; Marshall \& Peters, 1991; Snook, 1989) of the Treasury myth to persuade all but its staunchest supporters that it is unattainable and no longer serves a useful purpose, if it ever did. It is now time to adopt a new myth.

\section{The fourth educational myth: 2003 and Educated Citizens in a}

\section{Democratic Society}

New Zealand's first education myth was devised by a politician and lasted for some sixty years. The second, created by an educational bureaucrat, was written "overnight" but had a far longer gestation. It survived for nearly fifty years. The third, emanating from economists, is not destined to last much beyond fifteen years. Clearly, the shelf life of our education myths has diminished, but perhaps this trend can be reversed with a new myth. We cannot expect this to come from politicians, educational bureaucrats or economists, for currently all of them seem bereft of new ideas about education for the future. Indeed, Beeby (1992, p. 301) asks, "Is it impossible for a minister or an administrator to make a final definitive statement on the long-range objectives of the education system they control or administer? Whether a philosopher can do so is a different matter." As a philosopher, I accept the challenge.

Why so? Again, Beeby provides an insight:

As an administrator, I had spent twenty years too close to politicians, and to the demands of the public that supported them, 
to believe that any government would be foolish enough - or wise enough - to create a school system calculated to undermine the existing economic, social and political structure. As I have said earlier, I could only hope that the changes we were introducing into the schools would eventually produce a generation with more people determined to right existing wrongs. Too vague a hope, perhaps, to carry much conviction in 1990 but it would be a sad generation of educators that didn't harbour it. (p. 297)

I am of that generation: I entered primary school in the mid 1950s during the final years of Beeby's tenure as Director of Education; I learned of the Beeby/Fraser statement during my teacher education years, and since then I and many others have been heirs to Beeby/Fraser, determined to keep the torch alight, to "right existing wrongs".

Beeby (1992) observed that public opinion swings in two opposite directions along a predictable path: "Two competing concepts of fairness underlie the inexorable swing of public opinion on education - fairness to the individual and fairness to the county as a whole, its economy and its social structure" (p. 284). There is no going back to the Beeby/Fraser myth per se, yet there is something to be said about its value as a source of enlightened thinking about the nature of education and its inspirational provision to meet the competing demands of "fairness to the individual and fairness to the community". With this in mind I offer the following as guiding principles.

\section{Basic Principles}

In developing a new education myth, the fundamental assumption is made that every citizen has a right to become educated and that the state has a corresponding duty to provide this for all of its citizens. Becoming educated is not to be left to chance nor to idiosyncratic whim nor to the demands of business. Becoming educated goes beyond the good of the individual or of the economic imperative, encompassing as it does the social and moral good of the community as a whole. The right to education is an entitlement not to be denied a citizen, any citizen; it is too important to be left to children and their parents alone and too costly for them to provide unaided. And the economic interest, geared to capitalist surplus value or profit, is not to be trusted for there is little to give us confidence that this interest is the same as the individual or community interests. Since the modern community, as an organised mass of individuals, requires for its existence an educated populace, it is in the best interests of the community to demand and ensure that all of its citizens are educated to the extent that, while the individual benefits, so too does the whole. The good of an individual, counted as one, must be weighed up against the good of all, counted as the sum of the combined individual goods within which any one individual good may flourish, since the good of all shapes the good of one while the good of one, taken collectively, constitutes the good of the total. This dynamic relationship between the good of one and the good of all, in the matter of being educated, cannot be reduced to neat ascriptions of individual good and collective good, since both are mutually constitutive. If the child has a right to education, and if becoming educated is intimately coupled to the growth of an educated society, then the task of educating children to become educated adults is a task well beyond the resources of parents alone. Acting on behalf of all its citizens, in the general interest, the state rightly takes upon itself the duty to provide the resources for becoming educated well beyond that which families can be expected to furnish, and in doing so exercises its responsibility to provide an education which it can be sure meets the general demands of an educated citizenry. To leave this to the caprice of parents or the vagaries of the market is for the state to abrogate its obligation to ensure all of its citizens are educated.

That all citizens have a right to be educated, with the state having a corresponding duty to provide this, is an empty platitude until such time as the notion of becoming educated is spelled out. Talk about providing an education or becoming educated is not particularly helpful since it is far from clear what these entail. They aim for some end, an educated person, and it is the clarification of what it is to be an educated person that gives substance to the individual's right to education and the state's duty to ensure it through adequate provision. What, then, is an educated person? Or, to put it another way, what are the qualities that someone must possess in order to become an educated person? These qualities are certainly contestable, and have been contested at least as far back as Socrates, but there is nonetheless some general agreement over what does not count. Someone who is lacking in knowledge and therefore generally ignorant, or merely possessing a narrow range of vocational skills, however expert they may be in then, is not usually deemed to have 
met the criteria for being an educated person. One does not need to be gainfully employed to be an educated person and many are not (e.g., the retired) nor is an educated person one who unquestioningly abides by the law, for in some circumstances there may be good moral cause to breach a bad law (apartheid); conversely, one who regularly breaks good law (assaulting others) for immoral gain falls well short of the mark.

So, what are the qualities of an educated person? A preliminary point to note is this: we are born human but we must learn to become persons, and we learn to become educated persons in the company of those already educated. But not all become educated persons. Families have first call on the very young, but learning to become an educated person requires far more resources than families can normally provide. Persons possess a conceptual scheme from which they can generate ends to be achieved and the means of achieving them. They have a degree of consciousness, of themselves, of others and of the world at large, which allows them to navigate their way around. But more than this is required if persons are to become educated. There must be an ongoing broadening and deepening of one's conceptual scheme so that new and challenging problems can be addressed and, if possible, solved creatively. There is a growing awareness of how our developing understanding of the empirical world, moral judgement, aesthetic appreciation, emotional maturity, personal relationships and the like all contribute to the question "How ought I to live my life?" Learning which does not feed into reflection on the "good life", in a moral sense, has little educational value. Beyond this is the intrinsic worth of becoming educated: the love of learning for its own sake, the discovery of new things, the engagement in hitherto unknown activities, the acquisition of stimulating insights, the wonder about what is and what might be, creative hunches and novel solutions to new problems, and the rational challenge and critique of received wisdom where the individual is free to inquire as they may and autonomous in what they hold to be true, good or right. In short, an educated person is one, who in the Socratic sense, accepts that "the unexamined life is not worth living". An educated person is an ultimate end in itself. To ask, what is it a means to, is to ask what can be of greater good than being an educated person and in a secular world, I would argue there is none.

Given what has been said about the educated person, it is a not unreasonable expectation that, in order to become and remain educated persons, all citizens should have a right to participate in society to the extent that their interests allow. Each citizen has a right to be fully involved and none should be excluded from doing so. Participation in the affairs of the community will take various forms: some activities will conserve existing relations; others, being more radical, will necessarily involve greater conflict. The choices people make, and the actions they undertake, must be within boundaries robust enough to allow for continuity and change in ways that may alter, but not destroy, the basic moral fabric of the community.

To become educated persons requires a society which is free, fair and democratic. Socially, there must be maximum freedom for all to pursue their legitimate interests. If education is, in part, about the unfettered exploration of ideas, then society and schooling must be so organised to not only allow but also to encourage the freedom of the individual to pursue these ideas in a rigorous and systematic manner in order to test their truth, rightness or goodness. Freedom is necessary if received wisdom, especially that of those who rule, is to be subjected to the same critical scrutiny as the ideas of the ruled.

Freedom is also necessary for the advancement of new ideas which challenge tradition, for the entrenched positions are protected by power which is used to resist, even kill off, that which is a threat to established authority, be it religious, political, civil or military. No idea is immune from revision, even rejection; all citizens have an equal right to rationally propose and dispose of ideas with the full protection of the state and the endorsement of schools (even when these institutions are the defenders of the status quo).

Economically, there should be a fair distribution of resources and capital so that all citizens are able to obtain, or be provided with, a minimum level of pecuniary support to ensure that their educational achievements are not thwarted by more basic struggles to survive. No citizen should be placed in a position where their right to become an educated person and a participating citizen is denied them by virtue of poverty. This is not to demand an equal share for all in a capitalist society, but it is to stand firm on the claim for a fair share for all, consistent with a concern for the welfare of all.

Politically, the community and its schools should be built around the democratic process where decision-making is not only open to all to contribute to the debating of ideas and social practices, but also where the tyranny of the majority is not permitted to over-ride the interests of minorities. Only in a democratic society committed to the 
full flourish of ideas will its citizens become educated persons, for it is democracy, not dictatorship, which not only upholds an ideal of the educated person but openly works for its fulfilment in its citizens. Freedom has its greatest expression in an open society committed to the democratic process where ideas and social practices are widely discussed prior to acceptance or rejection. If a free and democratic society is to ensure that all of its citizens have an equal right to become educated persons, then it might ensure a fair distribution of resources to all of its citizens as a means of ensuring that the right to become an educated person is more than a pious platitude. It must become a lived reality. A social arrangement which rewards some enormously at the expense of other's penury is unlikely to have all of its citizens educated. Thus, the intervention of the state is required to ensure a degree of equity and limit the inequitableness of the market.

The intervention of the state is premised on the assumption that the agencies of the state will be so organized as to meet the demands placed upon them to assist young people to become educated persons and participating citizens. The government, in the form of the Minister of Education, and the bureaucracies under the Minister's aegis, including the Ministry of Education, Education Review Office, New Zealand Qualifications Authority, New Zealand Teachers Council and the Tertiary Education Commission, should all be focused and organised so as to ensure that their policies and practices are in accordance with, and directed towards, achievement of this educational aim. To reiterate Beeby's point made earlier, "the principle did lay down a general direction of desirable change and was a fairly reliable touchstone to test whether any programme for action fell within its limits."

The state should freely provide for the provision of educated persons in two senses. First, it should be free of charge to those receiving it, namely, children and their parents. There should be no cost for educational activities for learning and the resources required to achieve this. This is not to rule out some cost to parents by way, for example, of school uniforms and consumables (e.g., stationery). Second, it should be provided freely or unreservedly, held to be one of the greatest goods a community can give its younger members, regarded as an investment rather than a cost. That it should be given wholeheartedly is surely the hallmark of an educated citizenry and an enlightened state.
What is to be provided? The full resources of the state should be brought to bear to include financial, material, informational and human wherewithal. Financial expenditure must be extended as far as possible to give full effect to the aim of educating people; the material resources, including books, technology and the like must be provided; full, accurate and up to date information relevant to making decisions about educational progress must be forthcoming; and those adults centrally involved in educating the young - teachers in particular, but also school administrators and state bureaucrats - must themselves be educated persons deeply committed to the goal of bringing about educated persons.

Finally, the intervention of the state requires that the state shall have an active involvement in how the resources are to be used and for what purpose, to ensure that the educational needs and the social economic, political and civic interests of all are, as far as possible, met. In an unequal society, as ours is, the needs and interests of the least advantaged should be met first so that the total resources of the whole community are geared to the benefit of all its members becoming educated persons.

From this deliberation is a new myth born.

\section{The Myth}

It is the right of every citizen to become an educated person and to fully participate in and contribute to a free, fair and democratic society; it is the duty of the state to be organised so as to freely provide the resources and direct their use to equitably meet the social needs and economic interests of all its citizens.

Let the debate begin, for it is time to "right existing wrongs".

\section{References}

Apple, M. (1991). Ideology and the new right. In L. Gordon \& J. Codd (Eds.), Education policy and the changing role of the state. Palmerston North: Massey University, Delta Publications.

Beeby, C. (1986). Introduction. In W. Renwick (Ed.), Moving targets. Wellington: New Zealand Council for Educational Research

Beeby, C. (1992). The biography of an idea. Wellington: New Zealand Council for Educational Research. 
Bowen, C. (1877). Parliamentary debates, Vol. 23. New Zealand Parliament.

Clark, J. (1998). Education as a public good or in the public good? Implications for social justice. Delta, 50(1), 33-16.

Grace, G. (1991). The new right and the challenge of educational research. Cambridge Journal of Education, 21(3), 265-275.

Marshall, J. \& Peters, M. (1991). Educational "reforms" and new right thinking: An example from New Zealand. Educational Philosophy and Theory, 23(2), 46-57.

Renwick, W. (1986). Moving targets. Wellington: New Zealand Council for Educational Research.

Rivers, A. (1996, June 26). Interview. In M. Cusack, Social end products. New Zealand Education Review, p. 10.

Snook, I. (1989). Educational reform in New Zealand: What is going on? Access, 8(2), 9-18.

New Zealand Treasury. (1987). Government management. Brief to the incoming government, Vol II. Education Issues. Wellington: New Zealand Treasury.

Wellington Chamber of Commerce. (1933, December 8). A statement by a committee set up to consider a proposal to raise the school leaving age to 15 . The Sun, Christchurch.

\section{The author}

John Clark is a Senior Lecturer in the Department of Social and Policy Studies in Education, Massey University, Palmerston North. His teaching and research interests are in philosophy of education, especially ethics, curriculum, research and policy.

Email: J.A.Clark@massey.ac.nz 